\title{
Iniciación a la investigación científica: una experiencia de enseñanza desarrollada en una universidad argentina
}

\author{
Roxana Prósperi ${ }^{(1)}$, María Quirós ${ }^{(2)}$, Elsa Grimaldi ${ }^{(3)}$, \\ Liliana de Bianchetti ${ }^{(4)}$, Graciela Charpin ${ }^{(5)}$, \\ Estela Mattioli ${ }^{(6)}$ y Ana Cantora ${ }^{(7)}$
}

Palabras clave. enseñanza de la ciencia . géneros académicos $\cdot$ abstracts

Resumen. A partir del advenimiento de la sociedad del conocimiento, la ciencia y la tecnología se han constituido en pilares fundamentales de evolución económica y social. Para responder a esta demanda de la sociedad, la universidad debe asumir como una de sus tareas específicas el desarrollo de habilidades para la investigación científica, tomada como herramienta de procesos de enseñanza-aprendizaje y de producción intelectual. En este trabajo se presenta una experiencia llevada a cabo en una universidad argentina: una asignatura de estructura modular destinada a alumnos de grado que se inician en actividades de investigación en diversos campos disciplinares. Se describen las propuestas pedagógicas de los cuatro módulos que componen la asignatura y las conclusiones surgidas tras seis años de implementación.
Keywords. science instruction .

academic genres $\cdot$ abstracts

\begin{abstract}
Since the advent of the knowledge society, science and technology have become fundamental pillars of economic and social evolution. In order to respond to this demand, the development of specific skills for scientific research should be undertaken by the university as a tool of teaching-learning processes and intellectual production. This work presents an experience carried out in an Argentine university: a four-module course destined to undergraduates who are initiating a research career in different disciplinary fields. The pedagogical proposal of each module is described as well as the conclusions derived after six years of implementation.
\end{abstract}

\footnotetext{
(1) FBCB - UNL rprosperi@fbcb.unl.edu.ar (2) CCT - CONICET Santa Fe bases@ceride.gov.ar (3) INCAPE (CONICET, FIQ-UNL) grimaldi@fiq.unl.edu.ar
}
(4) FCM- UNL
ldebianchetti@gmail.com
(5) FHUC-UNL
(6) $\mathrm{FICH}-\mathrm{UNL}$
emattioli@fich1.unl.edu.ar
(7) FBCB - UNL
gcharpin@gmail.com 